\title{
The Challenges of e-Procurement Implementation in Infrastructure Projects
}

\author{
Alisia Ardita Rizki a * \\ ${ }^{a}$ Kementerian Pekerjaan Umum dan Perumahan Rakyat
}

\section{INFORMASI ARTIKEL}

\section{Article history:}

Data submission : 10 January 2018

$1^{\text {st }}$ revision: 11 February 2018

Accepted: 13 February 2018

Available online: 12 May 2018

Keywords: challenges, e-procurement, system implementation

\section{ABSTRACT}

This paper aims to explore the challenges of e-procurement implementation and how to overcome these challenges in infrastructure project of Ministry of Public Work and Housing. This study used secondary data analysis such as blue print, activity report, performance report and financial report. The data were collected on January 2018. The findings show that there are two key challenges of eprocurement implementation. Challenges in system specification are not only related to software integration and data management, but also legal and administration procedures and IT infrastructure. Challenges in implementation management are related to roll-out strategy and IT skills. However, there is no issue in IT outsourcing. Findings also show that there are impacts of eprocurement implementation on total cost of acquisition, organizational characteristics, and governance structure. Challenges can be overcome by establishing integrated e-procurement system and centralized database.

2018 FIA UB. All rights reserved.

\section{Introduction}

E-procurement has received increasing attention from government because of its benefit. Already, many private sectors have proved significant benefits from the implementation of e-procurement such as improved contract compliance, increased management information, reduced transaction cost and times (Sanders, 2007; Gunasekaran and Ngai, 2008). In public sector, it could make government to become more transparent because it system exchanges the information between public sector and their vendors. It also reduces procurement cost by reducing the use of paper, minimizing administrative duplication, and increasing transparency, accountability, and access to the public (OECD, 2016b). Leuwis Faupel et al. (2015) argues that e-procurement can overcome three common problems in manual procurement practices: lack of access to bid information, collusion among bides, and corruption. Therefore, a number of governments have adopted eprocurement (Leipold and World Bank, 2007).

The implementation of e-procurement also be adopted in procuring infrastructure
projects.Infrastructure is important because it is a key instrument in building environment that promotes economic growth. However, the quality of public infrastructure is still low (Briceño-garmendia, Estache, \&Shafik, 2004). Several reasons such as a limited supply of local qualified contractors, collusion among contractors, and corruption among public official have been presumed as the cause of this condition (Kenny, 2007). Therefore, it is important to overcome these problems and enhance good governance by implementing e-procurement.

Governance has become important issues in the field of development and government administration. Generally, governance can be defined as the manner in which power is exercised in the management of a country's economic and social resources for development (World Bank in Kauffman, Kraay, and Mastruzzi, 2010). Good governance is the process and structure that guarantee good management of resources (ADB, 2004). In public sector management, it focused on transparency and maximum benefits to the country, people, and society consistently and fairly. The principle of good governance is citizen participation,

* Corresponding author. Tel.: +62-341-553737; e-mail: alisia3003@gmail.com 
responsibility, rule of law, effectiveness, efficiency with equity and accountability.

To enhance good governance, Indonesia introduced e-procurement system in 2003 through Presidential Decree No. 80 Year 2003 on the Guidelines of the Procurement of Government Goods/ Services. In 2008, Indonesia government built INAPROC as eprocurement system to procure public good and services. Then in 2012, the use of-e-procurement system has become mandatory for all Indonesian Government based on Presidential Regulation No. 54 Year 2010 on the Procurement of Government Goods/Services. However, Ministry of Public Work and Housing developed e-procurement system since 2002. They use their own system to procure infrastructure projects because they have different working characteristics and complexities that INAPROC cannot provided until now. In addition, infrastructure is important because it is one of the key investment projects (ADB, IDB, \& World Bank, 2004). Therefore, Ministry of Public Work and Housing have to ensure the sustainability of the projects by using its own system. Now, that is over a decade since the adopting of eprocurement. Ministry of Public Work and Housing should explore the challenges of e-procurement implementation in order to achieve good governance. This paper will address two questions:

a) What are the challenges of the e-procurement implementation in infrastructure project?; and

b) How does government overcome these challenges to enhance good governance in this sector?.

There has been some research in exploring public sector procurement (Moon, 2005, Croom and BrandonJones, 2007, and Doherty, McConnell, and Ellis Chadwick, 2013). Some studies focus on examining the implementation benefit, risk, and failures (Croom, 2000, Losh and Lambet, 2007 and Chang et al., 2008). Aman and Kasimin (2011) explore the implementation challenges of e-procurement and how to overcome these challenges. However, those research do not explore the impact of successful procurement implementation in infrastructure projects. Therefore, in this paper I address this gap by exploring the challenges of e-procurement implementation in this sector. The research will adopt Aman and Kasimin's research in 2011.

\section{Theory}

Procurement is the process of acquisitioning goods and services by an organization. However, the procurement steps are the major problem for good governance (Rotchanakitumnuai, 2013). The interaction between government and supplier can cause corruption in procurement (Hui et al., 2011). After the development of information technology, there is a system reduced the steps of procurement process called e-procurement. It uses internet to reduce cost and time, change purchasing routine, and build relationships with suppliers (Chopra et al., 2001, Davila et al., 2003, Rotchanakitumnuai, 2013). It is the system that can enhance transparency and achieve good governance in procurement (Heywood, 2002).
Researchers have studied the challenges of eprocurement implementation in public sector. Croom and Brandon-Jones (2007) have found five key challenges of procurement implementation which are system specification, implementation management, changes to organizational characteristic, changes in total acquisition costs, and changes to governance structures. Aman and Kasimin (2011) showed that there are other key challenges that government should overcome. It is not only software integration, data management and roll-out strategy but also legal and administration procedures, information technology (IT) infrastructure, outsourcing contract and IT skills.

\begin{tabular}{|c|c|c|}
\hline Authors & Issue of study & $\begin{array}{l}\text { Research } \\
\text { Method }\end{array}$ \\
\hline Croom (2000) & $\begin{array}{l}\text { The impact of web-based } \\
\text { order processing systems } \\
\text { for procurement strategy in } \\
\text { the management of } \\
\text { maintenance, repair, and } \\
\text { operating (MRO) supply }\end{array}$ & $\begin{array}{l}\text { Exploratory } \\
\text { study }\end{array}$ \\
\hline $\begin{array}{l}\text { Hackney et al. } \\
(2007)\end{array}$ & $\begin{array}{l}\text { Evaluation issues related } \\
\text { to eReverse auction }\end{array}$ & Case study \\
\hline $\begin{array}{l}\text { Croom and } \\
\text { Brandon-Jones } \\
(2007)\end{array}$ & $\begin{array}{l}\text { The evaluation of e- } \\
\text { procurement } \\
\text { implementation and } \\
\text { operation from of e- } \\
\text { procurement five key } \\
\text { themes are considered } \\
\text { system specification, } \\
\text { implementation } \\
\text { management, changes to } \\
\text { organizational } \\
\text { characteristics, changes in } \\
\text { total acquisition costs, and } \\
\text { changes to } \\
\text { governance structures }\end{array}$ & Qualitative \\
\hline $\begin{array}{l}\text { Aman and Kasimin } \\
\text { (2011) }\end{array}$ & $\begin{array}{l}\text { The impact of system } \\
\text { specification } \\
\text { implementation } \\
\text { management on } \\
\text { procurement system }\end{array}$ & Qualitative \\
\hline $\begin{array}{l}\text { Doherty, } \\
\text { McConnell, and } \\
\text { Chadwick (2009) }\end{array}$ & $\begin{array}{l}\text { Exploring the drivers, } \\
\text { scope and perceived } \\
\text { success of e-commerce } \\
\text { strategies in the UK retail } \\
\text { sector }\end{array}$ & Qualitative \\
\hline $\begin{array}{l}\text { Rotchanakitumnuai } \\
\text { (2013) }\end{array}$ & $\begin{array}{l}\text { The governance evidence } \\
\text { of e-government } \\
\text { procurement }\end{array}$ & Quantitative \\
\hline $\begin{array}{l}\text { Lewis-Faupel et al } \\
(2015)\end{array}$ & $\begin{array}{l}\text { The impact of e- } \\
\text { procurement } \\
\text { infrastructure provision }\end{array}$ & Quantitative \\
\hline
\end{tabular}

\subsection{E-Procurement}

\subsubsection{Definition of E-Procurement}

Oliveira and Amorim (2001) define e-procurement as the process of electronically purchasing the goods and services which are needed for an organization's operation. It provides significant opportunity to reduce 
cost, increase organization effectiveness, and improve services. It gives promise that public contract's winner is the one who offers best value for money.

Raghavan and Prabhu (2004) use the definition of eprocurement which is "the electronic acquisition of goods and services including all processes from the identification of a need to purchase of products, to the payment for these purchases, including post-contract/ payment activities such as contract management, supplier management and development.

LKPP, 2010, states that e-procurement is the procurement of goods/ services conducted by using information technology and electronic transaction based on regulation.

An e-procurement technology is defined as technology designed to facilitate acquisition of good by a private or public organization over the internet. It focuses on automating workflows, consolidating and leveraging organizational spending power, and identifying new sourcing opportunities through the internet (Davila et al., 2003).

\subsubsection{E-procurement in Ministry of Public Sector and Housing}

The Ministry of Public Work and Housing began developing e-procurement system in 2002. It began with semi-electronic procurement system in 2004 in central ministry in Jakarta and expanded the procedure across 33 provinces over the next 5 years. In semi-electronic procurement, the companies are able online to register interest projects, to download detailed bidding and technical qualification documents, to submit prequalification materials, and to post question and complaints. The semi-electronic procurement covers the entire procurement process except the final submission of bids. The system and procedure followed the presidential guidelines for the procurement of government good and services issued in 2003 (Government of Indonesia in Lewis, 2016). Now, The Ministry of Public Work and Housing used eprocurement system provided by The Agency for Government Procurement of Goods or Services (LKPP).

In 2010, Ministry of Public Work and Housing implemented e-procurement system with full-electronic procurement. The procurement process is conducted by online, except qualification verification. It is because the limited infrastructure of technology and information. However, this system reduced the possibilities of corruption. According to the Bribe Payers Index (BPI) of Transparency International in 2002, the highest bribe payment in procurement in Indonesia is in the public work and construction sector (ADB \& OECD, 2008).

The development of e-procurement has conducted through several steps:

a) Copy to Internet is the activities of viewing the entire process and the results of the procurement of goods/ services, broadcast via the internet by the procurement team; b) Semi-electronic Procurement is the procurement of goods/ services where the half of the process is conducted through electronic media (internet) between service users and service providers and other is by manual process; and

c) Full-electronic procurement is the process of selecting providers of goods/ services by uploading an offer document through E-Procurement system, while the explanation of the selection document/ tender (Aanwizjing) is still done face to face between the service user by the service provider.

Moreover, the development of e-procurement in Ministry of public work and housing is explained in following table.

Table 2.2. The Development of E-procurement

\begin{tabular}{|c|l|l|}
\hline No & \multicolumn{1}{|c|}{ Tahun } & \multicolumn{1}{|c|}{ Development of E-Procurement } \\
\hline 1. & $2002-2003$ & Trial (CTI) \\
\hline 2. & $2004-2008$ & Semi e-procurement \\
\hline 3. & $2009-2010$ & Semi E-Procurement Plus \\
\hline 4. & $2010-2015$ & Full E-procurement \\
\hline 5. & $2016-$ now & SIRUP (provided by LKPP) \\
\hline
\end{tabular}

\subsubsection{Key Challenges of The E-procurement Implementation}

\subsubsection{System Specification}

Croom and Brandon (2007) stated that system specification is the critical issue in the implantation of eprocurement. Challenges in system specification consist of two problems; software integration and data management. Software integration is used to know the extent to which e-procurement system is able to integrate with other information system. Whereas data management is data entry and the coding scheme employed. Issues in system specification include hardware resources, network resources, and web server, while issues in data management include are limited levels of management information about expenditure, product and service specifications in the main issues in system specification. Despite that, system specification in developing countries also includes legal and administrative procedures (Aman and Kasimin, 2011). This notion is supported by Subramaniam \& Shaw (2002) that indicated legal and administration procedure as key challenges in system specification. Moreover, Kasim and Hussin (2010) found that bandwidth, computing and information system architecture are the issues that is faced by small suppliers. The finding is similar with Aman and Kasimin (2011). He shows that one of the challenges of e-procurement implementation is IT infrastructure especially in rural area.

\subsubsection{Implementation Management}

Implementation management is the process of eprocurement system delivery to end users (Croom and Brandon, 2007). They explain that roll-out strategy of eprocurement can be either an informal "evolutionary" protocol or a formal "project board". The evolutionary protocol involves internal design and development of a 
bespoke system, which consequently involved gradual system development and roll-out. Sumadilaga and Pudjijono (2011) found that there is a gradually implementation of e-procurement system in infrastructure projects.

The 'project board protocol' was typically employed by large organizations who undertook a formal appraisal and sourcing approach to the purchase of a third-party eprocurement system In addition, developing countries face other challenge which is outsourcing contract (Auriol, 2009). According to him, to implement eprocurement system government need to outsource third party. However, outsourcing contract has a service fee charge resulting in burdening the users. and $\mathrm{Ng}$ (2003) point out the difference pocess of pre and post e-procurement. They discovered evidence that the change in delivery process can reduce costs. The cost of processing purchase requisitions was reduced through improvements to the procurement system, but also the reduction in maverick purchasing (Croom and Brandon, 2007). Sumadilaga and Pudjijono (2011) also stated that e-procurement system increases cost efficiency. For supplier, they can reduce transportation and document cost.

\subsubsection{Changes to Organizational Characteristics}

There are also many studies that examined the nature of behavior and relational changes to organizations and their supply chain as a result of adoption. Kennedy and

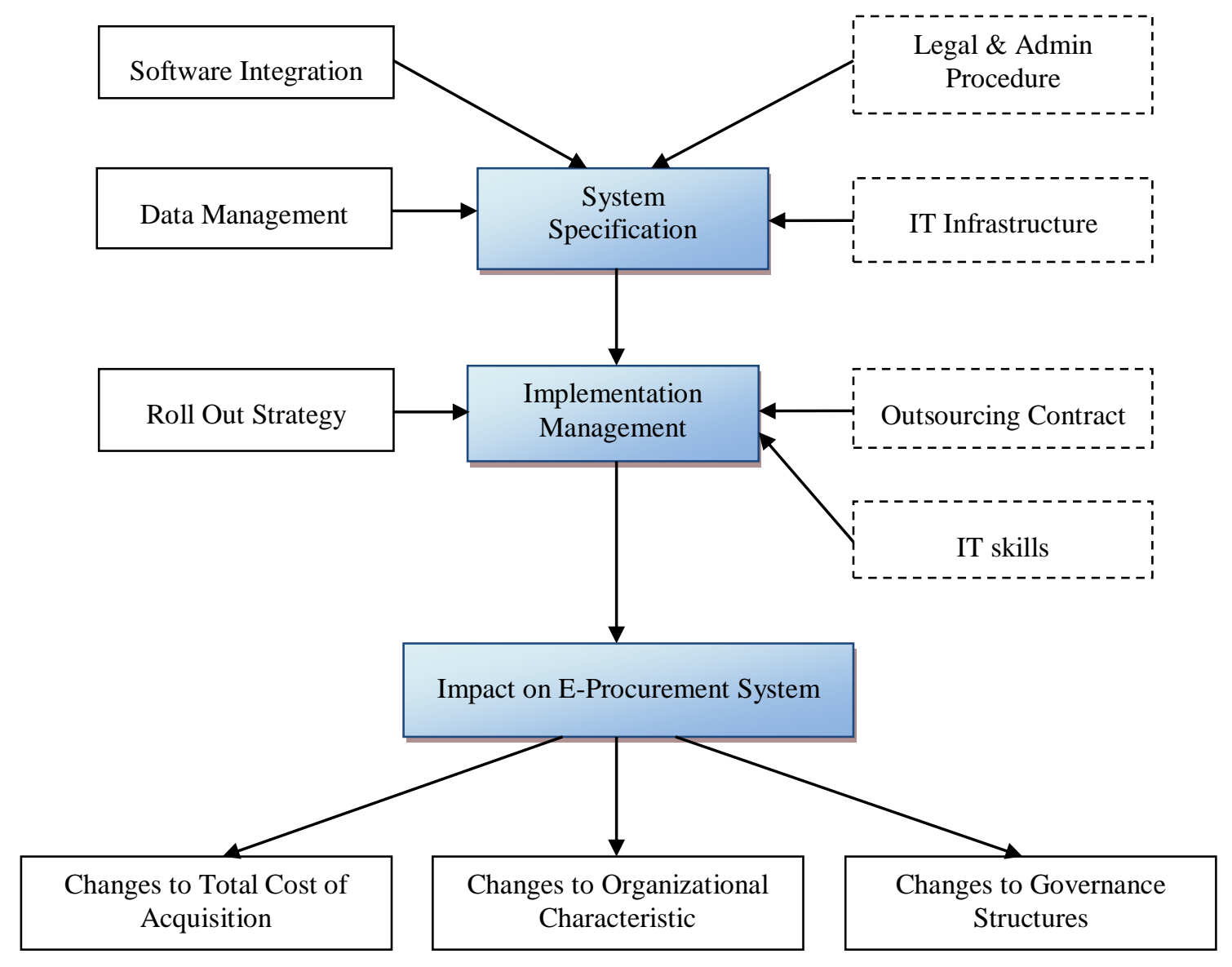

Figure 2.1. Theoretical Framework: The Challenges of E-Procurement Implementation Source: Aman and Kasimin, 2011

Another important challenge in implementation management is IT skills (Heeks, 2006). Kassim and Hussin (2010) and Liao et al. (2003) show difficulties faced by suppliers due to tedious procedures and lack of IT skills to perform e-procurement transactions. Aman and Kasimin (2011) also found that challenges of eprocurement implementation are related to IT skills.

\subsubsection{Changes to Total Acquisition Costs}

Recent studies have found that e-procurement system can reduce costs (Croom 2000, Kameshwaran and Narahari, 2007). Some researchers also argue that it will have implication to the process of e-procurement. Yen
Deeter-Schmelz (2001) have examined the motivation of organization to use internet. E-procurement is used and developed is strongly influenced by general disposition of the organization as the whole.

\subsubsection{Changes to Governance Structures}

The influence of improved information transmission and user access to the procurement process through the adoption of e-procurement has a significant impact on the configuration and structure of supply chains. Croom (2000) notes that the literature posits two opposing schools of thought on the subject. 
On one side, they may increase the tendency towards market transactions as the barriers to participate in electronic transactions diminish. Barratt and Rosdahl (2002) argue that ease of search and transparency acts as an advantage to the buyer but which further reinforces market-based relationships under e-procurement. On the other side, it has been posited that the proprietary nature of some inter-organizational systems may in fact serve to tie in customers and suppliers into virtual hierarchies (Konsynski and McFarlan, 1990). Evans and Wurster (2000) claim that the low infrastructure and transaction costs of Internet-based systems allow organizations to exploit the increased opportunities for complex information exchange with multiple partners, but also recognize the value to be gained through closer, hierarchical, relationships between regular trading partners.

From the explanation above, there is a theoretical framework that I used to analyze this study (figure 2.1).

\section{Research Method}

This study used secondary data analysis which is content data analysis. The study conducted in Eprocurement services (LPSE) of Ministry of Public Work and in January 2018. In this study, I focus the case of the e-procurement implementation in infrastructure project because Ministry of public Work and Housing is the pioneer in implementing e-procurement system.
Then, the documents were analyzed by identifying issues and development of the theme.

\section{Results and Discussion}

This paper aims to explore the challenges of eprocurement implementation and how to overcome these challenges in infrastructure projects of Ministry of Public Work and Housing. The findings show that all of the key challenges of e-procurement implementation were exist. This evidence support the argument of Croom and Brandon-Jones (2007), Aman and Kasimin (2011), Losch (2007), and Lambert (2007) and Chang et al. (2008). In this section, I present findings according themes in theoretical framework. The findings show that there are two key challenges of e-procurement implementation in infrastructure project.

\subsection{System Specification}

The main challenge in system specification is related to lack of integration with other systems. In this case, Ministry and Public Work and Housing has problem in integrating e-procurement with budgeting, and monitoring system. Budgeting system (RKAKL), and monitoring system (e-Monev). RKAKL is developed by Ministry of Finance whereas e-Monev is developed by Ministry of Public Work and Housing itself. The procurement performance in infrastructure projects is depends on these two systems. All of infrastructure

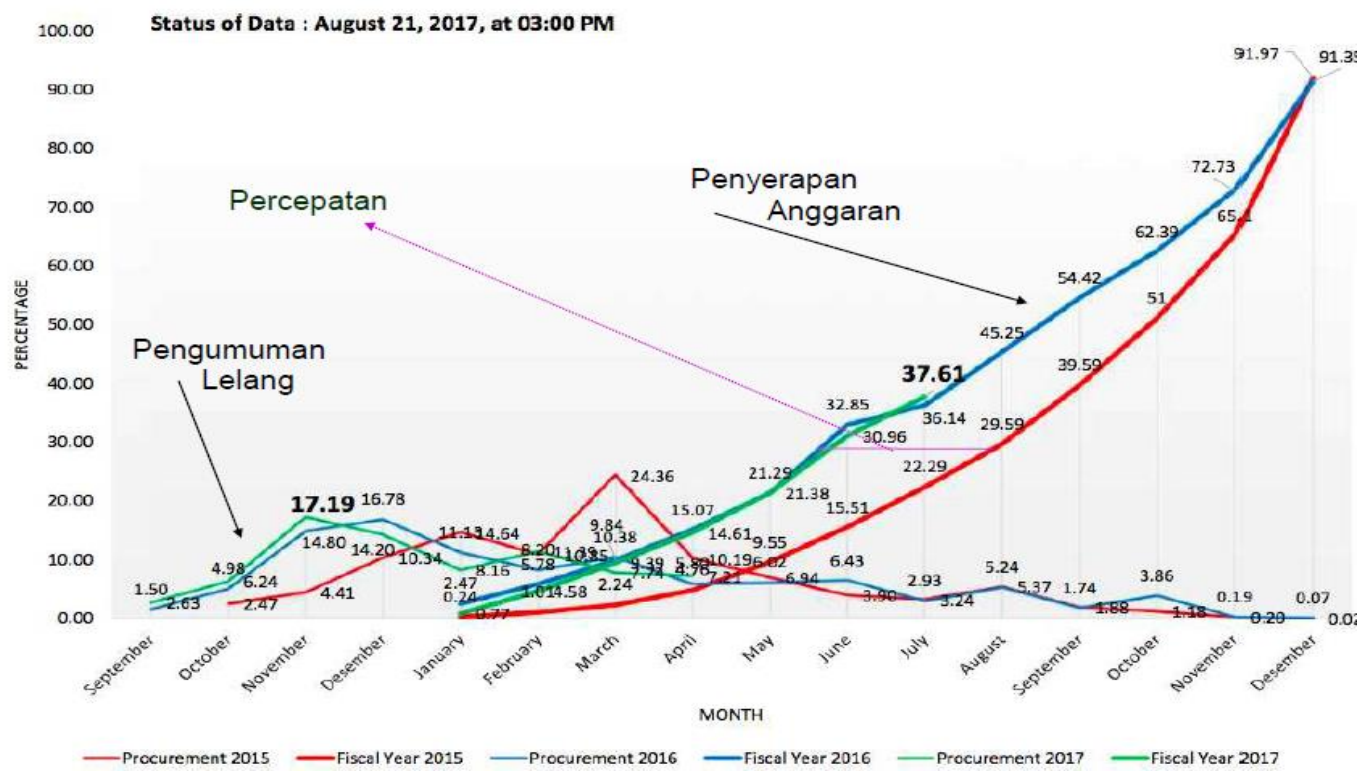

Figure 4.1. Accelerated Budget Realization Chart

Source: E-procurement services, Ministry of Public Work and Housing, 2017

They had adopted it before Indonesia government obligated to adopt system. The system was developed by LKKP called SIRUP. Ministry of Public Work and Housing just has implemented this new system. In addition, e-procurement in infrastructure project has different characteristic and complexities. Data were collected from document reviews such as blue-print, performance report, activity report, and financial report. packages must be compiled first in RKAKL. It will be ratified in November. However, The Ministry of Public Work and Housing have to conduct earlier procurement which is in August because the complexity of the work on infrastructure projects. It is conducted to accelerate infrastructure performance and avoid projects delay The Ministry of Public Work and Housing can announce project winners earlier by conducting earlier procurement. Thus, infrastructure projects can be 
immediately undertaken by contractors. Data that earlier announcement of project winner accelerate budget realization can be seen in the following chart (figure 4.1).

The finding supports with prior research by Aman and Kasimin (2011). They found that the performance of e-procurement is affected by other performance of the two financial system. Rajkumar (2001) and Subramanian and Shaw (2002) also point out that system specification was found to be critical to the operational performance of the e-procurement system.

In order to minimize such software integration issue, The Ministry of Public Work and Housing and Ministry of Finance must agree to integrate RKAKL into e-procurement. The Ministry of Public Work and Housing also has to integrate their e-monev with eprocurement. However, it is difficult to achieve due to legal and administration policy. Previous study (Kassim and Hussin, 2010) found that the degree of software integration in e-government often involved legal and administration policy. Despite that The Ministry of Public Work and Housing has prepared a plan to integrate these two systems called Development of Integrated Procurement System Based Information Technology. This system is expected to enhance eprocurement performance and data security. In addition, the integrated system will facilitate either suppliers or government to access data and monitor progress of the projects. Integrated e-procurement system can be seen in the following figure 4.2 . need to use redundant bandwidth management. Internet connection in The Ministry of Public Work and Housing has used redundant internet connections which are Data Center 1 (DC1) and Data Center 2 (DC2). However, DC2 is recommended to use dual-home to enhance its performance. In addition, there are some problems in remote areas related to implementing e-procurement. Supplier and government agencies located in remote areas have difficulty in access internet and electricity services. Based and Activity Report, in Lamandau Regency power outage is often occur. It is already anticipated by using the generator in the office LPSE as a backup for the operational support LPSE. However, the generator cannot operate due to abnormal voltage. The findings in line with Aman and Kasimin (2011) theory which explain that IT infrastructure is one of challenges in system specification.

Challenge in data management in Ministry of Public Work and Housing is the difficulty in accessing data. The data includes contract addendum, blacklist, billing rate, unit price and products. Procurement data is scattered throughout the procurement service unit so it is difficult to access. Especially when monitoring and evaluating a project. In addition, there is no centralized data back up of an electronic procurement document. Therefore, the document is unsecure. It could have lost if there is a disaster. To overcome this problem, Ministry of Public Work and Housing has drafted a plan to centralize procurement data in one database.

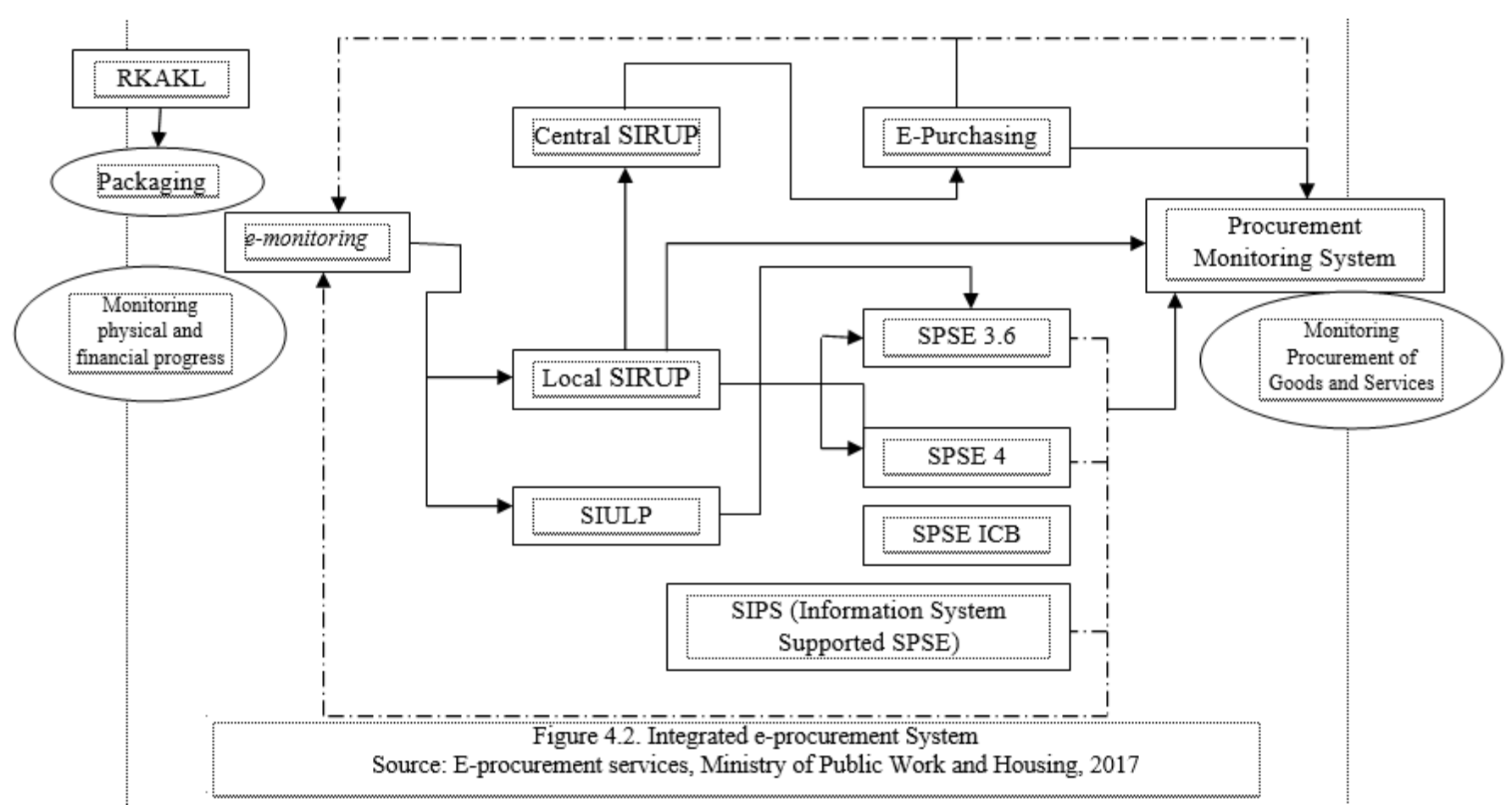

The findings also show that there is a challenge related to lack of IT infrastructure. It includes hardware resources, network resources, and web server. Bandwidth management and internet connection are the problem that should get attention from The Ministry of Public Work and Housing. Blue Print suggests that they

\subsection{Implementation Management}

Findings show the use of formal "project board" protocol (Croom and BrandonJones, 2007) to ensure successful of e-procurement implementation. The participation of e-procurement is mandatory to all 
government agencies and suppliers. However, Ministry of Public Work and Housing had initiated to implement e-procurement system before government enacted regulation that every government institution has to adopt this system. The Ministry decided to adopt the eprocurement to simplify the procurement process. The system is gradually implemented to avoid resistence and increase acceptability. At the beginning of the implementation of E-Procurement, the Internet is a relatively new thing known by the public. Stakeholders was not ready if Ministry of Public Work and Housing applied full e-procurement, It would inhibit and slow down the procurement process resulting in a delay in the implementation of infrastructure projects for public works. The finding in line with Sumadilaga and Pudijono (2011) who stated that e-procurement system was gradually implemented in infrastructure sector.

Findings also show challenges related to lack of IT skills. IT staffs who have skills in the field of information technology, particularly related to the application software still inadequate, so that if there are technical problems, it will take time to solve the problem.. E-procurement in Ministry of Public Work and Housing requires qualified staff to perform as system administrator. However, the number of staffs that can hold such roles is insufficient. Based on Blue Print, Ministry of Public Work and Housing still needs 9 persons who have IT skills as system administrator, network administrator, and database administrator. The finding supports with prior research by Heeks (2006) Kassim and Hussin (2010) and Liao et al. (2003), and Aman and Kasimin (2011). They stated that eprocurement performance is strongly influenced by IT skills. In order to overcome this challenge Ministry of Public Work and Housing is actively hiring contract workers and joining training provided by LKPP.

The findings show that there is no outsourcing issues of e-procurement implementation in infrastructure projects. At the first time, e-procurement system has been built and developed by Ministry of Public Work and Housing. It covered all of packages in infrastructure projects. Then, government had a concern to implement e-procurement system to all of institution. Government issued Presidential Decree No. 80 Year 2003 and pointed out The Agency for Government Procurement of Goods or Services (LKPP) to develop information systems as well as supervise procurement of goods/services electronically. Now, the e-procurement system is provided by LKPP. Ministry of Public Work and Housing as an administrator of the system does not have outsourcing contract with third-party. This is contrast to Auriol (2009) who claims that the outsourcing vendors are free to set output level of eprocurement.

\subsection{Implications}

The findings imply that there are two key challenges of e-procurement implementation using a case study in Ministry of public Work and Housing. The paper highlights the need to understand challenges and limitations faced by government especially Ministry of Public Work and Housing. The paper provides a basis for further thought and analysis on important issues such as lack of IT infrastructure and skills that need to be overcome in order to gain impact on e-procurement system.

\section{Conclusion}

This study concludes that the challenges of eprocurement implementation in infrastructure project can be categorised into system specification and implementation management. Challenges in system specification are not only related to software integration and data management, but also legal and administration procedures and IT infrastructure. Moreover, challenges in implementation management are related to roll-out strategy and IT skills. However, there is no issue in IT outsourcing. Findings also show that there are impacts of e-procurement implementation on total cost of acquisition, organizational characteristics, and governance structure. Challenges which are system specification and data management can be overcome by establishing integrated e-procurement system and centralized database.

\section{References}

ADB. (2004). Promoting Good Governance: ADB's Medium-Term Agenda and Action Plan. Available at

https://www.adb.org/sites/default/files/institutiona 1-document/32845/files/promoting-good governance.pdf [Accessed on 27 July 2017].

ADB, IDB, \& World Bank. (2004). Strategic Electronic Government Procurement - Strategic Overview: an Introduction for Executives. Available at http://documents.worldbank.org/curated/en/79499 1468152096524/pdf/882520WP0Box380icOvervi ew0March2004.pdf [Accessed on 27 July 2017].

ADB., \& OECD. (2008). Managing Conflict of Interest: Frameworks, Tools, and Instruments for Preventing, Detecting, and Managing Conflict of Interest. Available at https://www.adb.org/sites/default/files/publication 127975/managing-conflict-interest.pdf [Accessed on 27 July 2017].

Aman, Aini and Kasimin, Hasmiah. (2011). Eprocurement implementation: a case of Malaysia Government. Transforming Government: People, Process, and Policy, Vol. 5 No. 4, 2011 pp. 330344.

Auriol, E. and Picard, P.M. (2009). Government Outsourcing: Public Contracting with Private Monopoly. The Economic Journal, Vol. 119, pp. 1464-93.

Barratt, M., \& Rosdahl, K. (2002). Exploring Businessto-Business Marketsites. European Journal of Purchasing and Supply Management, Vol. 2, No. 8, pp. 111-122.

Briceño-Garmendia, Cecilia, Antonio Estache., \& Nemat Shafik. (2004). Infrastructure Services in Developing Countries: Access, Quality, Costs and Policy Reform. World Bank Policy Research Working Paper 3468. 
Center for Data and Information Technology. (2016). Eprocurement Report Year 2016. Ministry of Public Work and Housing, Jakarta.

Center for Data and Information Technology. (2017). Eprocurement Report Year 2017. Ministry of Public Work and Housing, Jakarta.

Chang, H.-L., Wang, K., \& Chiu, I. (2008). Business-IT Fit in E-procurement Systems: Evidence From High-Technology Firms in China. Information Systems Journal, Vol. 18, No. 4, pp. 381-404.

Chopra, S., Dougan, D., \& Gareth, T. (2001). B2B ECommerce Opportunity. Supply Chain Management Review, Vol. 5, No. 3, pp. 50-62.

Croom, S.R., \& Brandon-Jones, A. (2007), Impact of Eprocurement: Experiences From Implementation In The UK Public Sector. Journal of Purchasing \& Supply Management, Vol. 13, No. 4, pp. 294303.

Croom, S. (2000). The Impact of Web-Based Procurement on The Management of Operating Resources Supply. Journal of Supply Chain Management, Vol. 36, No. 1, pp. 4-13.

Davila, A., Gupta, M., \& Palmer, R. (2003). Moving Procurement Systems to The Internet: The Adoption and The Use af E-procurement Technology Model. European Management Journal, Vol. 21, No. 1, pp. 11-23.

Doherty, Neil F., McConnell, Danny J., \& Ellis Chadwick, Fiona. (2013). Institutional Responses to Electronic Procurement in The Public Sector. International Journal of Public Sector Management, Vol. 26, Issue: 6, pp. 495515

Doherty, N.F. and Ellis-Chadwick, F.E. (2009). Exploring The Drivers, Scope and Perceived Success of E-commerce Strategies in The Uk Retail Sector. European Journal of Marketing, Vol. 43 Nos 9/10, pp. 1246-1262.

Evans, P., \& Wurster, T.S. (2000). Blown to Bits: How The New Economics Of Information Transforms Strategy. Harvard Business School Press, US.

Gunasekaran, A., McGaughey, R.E., Ngai, E.W.T., and Rai, B.K. (2009). E-procurement Adoption in The South Coast SMEs. International Journal of Production Economics, Vol. 122, No. 1, pp. 161175.

Hackney R., Loesch A., Irani Z., Ghoneim A., \& Ozkan, S. (2007). Evaluating eReverse auctions (EeRa): A Case Research Note. Transforming Government: People, Process and Policy, Vol. 1, No. 1, pp. 59-66.

Heeks, Richard. (2006). Understanding and Measuring E- government: International Benchmarking Studies. Available at http://unpan1.un.org/intradoc/groups/public/docu ments/un/unpan023686.pdf [Accessed on 10 August 2017].

Heywood, J.B. (2002). e-Procurement: Managing Successful e-Procurement Implementation. Harlow, NJ: Financial Times - Prentice Hall.

Hui, W. S., Othman, R. O., Normah, O., Rahman, R. A., \& Haron, N. H. (2011). Procurement Issues in Malaysia. International Journal of Private Sector Management, 24(6), pp. 567-593.
Kassim, E.S. and Hussin, H. (2010). Public eprocurement: a research synthesis, Proceeding of the International Conference on e-Education, $e$ Business, e-Management and e-Learning, IC4E, Hong Kong, pp. 150-4.

Kauffman, Daniel., Kraay, Aart., \& Mastruzzi, Massimo. The Worldwide Governance Indicators: Methodology and Analytical Issues. Available at http://info.worldbank.org/governance/wgi/pdf/wgi .pdf [Accessed on 01 August 2017].

Kennedy, K.N., \& Deeter-Schmelz, D.R. (2001). Descriptive and Predictive Analyses of Industrial Buyer's Use of Online Information For Purchasing. Journal of Personal Selling \& Sales Management, Vol 21(4), pp 279-290.

Kenny, Charles. (2007). Construction, Corruption, and Developing Countries. Policy Research Working Paper; No. 4271. World Bank, Washington, DC.

Konsynski, B.R., \& McFarlan, F.W. (1990). Information Ppartnerships - Shared Data, Shared Scale. Harvard Business Review, Sept/Oct, pp. 114-120 .

Leipold, Knut., \& World Bank. (2007). Electronic Government Procurement (e-GP): Opportunities and Challenges. Available at https://www.uncitral.org/pdf/english/congress/Lei pold.pdf [Accessed on 10 August 2017].

Lewis, Blane D. (2016). Local Political Fragmentation: Fiscal and Service Delivery Effects in Indonesia. Departmental Working Papers 2016-16. The Australian National University, Arndt-Corden Department of Economics, Australia.

Lewis-Faupel, Sean, Yusuf Neggers, Benjamin A. Olken, and Rohini Pande. (2015). Can Electronic Procurement Improve Infrastructure Provision? Evidence from Public Works in India and Indonesia. American Economic Journal: Economic Policy, 8(3): pp. 258-83.

Liao, S-H., Cheng, C-H., Liao, W-B., \& Chen, I-L. (2003). A Web-Based Architecture For Implementing Electronic Procurement in Military Organisations. Technovation, Vol 23(6), pp. 521532.

Losch, A. and Lambert, J.S. (2007). E-reverse Auctions Revisited: An Analysis of Context, BuyerSupplier Relations and Information Behavior. Journal of Supply Chain Management, Vol. 43, No. 4, pp. 47-63.

Moon, M. (2005), E-procurement Management in State Governments: Diffusion of E-procurement Practices and Its Determinants. Journal of Public Procurement, Vol. 5, No. 1, pp. 54-62.

OECD. (2016). OECD Public Governance Reviews: Public Procurement Review of Mexico's Pemex, Adapting To Change In The Oil Industry. Available https://www.oecd.org/gov/ethics/PEMEX-

at procurement-review-highlights.pdf [Accessed on 10 August 2017].

Oliveira, L. M. S., \& Amorim, P. P. (2001). Public EProcurement. International Financial Law Review, (20:3), pp. 43-47.

Raghavan SNR., \& Prabhu, M. (2004). Object-Oriented Design of A Distributed Agent-Based Framework 
For E-procurement. Prod Plan Control, 15(7): pp. 731-741.

Regulation of The Minister of Public Work and Housing Number 35/PRT/M/2016. Blue Print of Information Technology and Communication.

Rajkumar, T. M. (2001). E-Procurement: Business and Technical Issues. Information Systems Management, Fall, Vol. 18(4), pp 52-60.

Rotchanakitumnuai, Siriluck. (2013). The Governance Evidence of E-government Procurement. Transforming Government: People, Process, and Policy. Vol. 7, Iss 3, pp. 309 - 321.

Sanders, N.R. (2007). An Empirical Study of The Impact of E-business Technologies on Organizational Collaboration and Performance. Journal of Operations Management, Vol. 25, No. 6, pp. 1332-1347.

Subramaniam, C., \& Shaw, M.J. (2002). A Study on The Value And Impact Of B2B E-commerce: The Case of Web-Based Procurement. International Journal of Electronic Commerce, Vol. 6, No. 4, pp. $19-40$.

Sumadilaga, Danis Hidayat., \& Pudjijono, Agus. (2011). Kendala, Keberhasilan dan Tantangan dalam Sembilan Tahun Pelaksanaan e-Procurement di Kementerian PU dalam Mencapai Good Governance. Konferensi Teknologi Informasi dan Komunikasi untuk Indonesia 14-15 Juni 2011, Bandung.

Yen, B P-C., \& Ng, E.O.S. (2003). The Impact of Electronic Commerce on Procurement. Journal of Organizational Computing and Electronic Commerce. Vol 13 (3\&4), pp 167-189. 